\title{
Valuable Dental Materials from Salvadora Persica Plants
}

\author{
Salah A. Jassim ${ }^{1}$, Kafa K. Hammud ${ }^{2}$, Bassam Alsheekhly ${ }^{3}$ \\ ${ }^{1}$ Professor, College of Dentistry, Al Iraqia University, Baghdad, Iraq, ${ }^{2}$ Research Scholar, Directorate of Materials \\ Research, Ministry of Science and Technology, Baghdad, Iraq, ${ }^{3}$ Tutor, College of dentistry, Al Iraqia University, \\ Baghdad, Iraq
}

\begin{abstract}
Due to their popular uses, Salvadora persica (Miswak) plant possesses several bioactive effects and it is important to focus on their valuable effectiveness, especially on dental and oral health. The present review deals with many sections to obtain suitable knowledge about miswak such as chemical compositions, bioactivity, partitioning of active materials, method of obtaining miswak extract and the potent of this plant on dental and oral health according to their antioxidant, antifungal, antibacterial, antimicrobial, antiphlogistic, antimycotic, anticarcinogenic, anticandidal, anti-inflammatory and anti-plaque properties.
\end{abstract}

Keywords: Miswak, Salvadora persica, compositions, bioactivity, dental.

\section{Introduction:}

Salvadora persica L. (Miswak) is a tree from Salvadoraceae family, Mongnoliopsida Class naturally grown in the Saudi Arabia, Iran, India, and parts of Africa and are spread to all Islamic countries. By World Health Organization (WHO), it is considered as a safe tool for oral tooth hygiene. It has several known names derived from "Miswak" word like siwak, sewak, miswak beside $\operatorname{arak}^{(1)}$.

Chewing sticks of Salvadora persica have different names in different languages, such as miswak, mastic, koyoji, in Arabic, Latin and Japanese languages respectively ${ }^{(2)}$.

Miswak is a natural plant widespread and used as an effective oral hygiene tool depending on its chemical, medicinal, and mechanical characters ${ }^{(3,4,5)}$. Miswaq, arak or chewing sticks are different synonyms for a plant which was used before 7000 years ago by Babylonians,

\section{Corresponding Author:}

\section{Prof. Dr. Salah A. Jassim}

Professor, College of Dentistry, Al Iraqia University,

Baghdad, Iraq

e-mail: drsalahalmula@gmail.com

Mobile: +9647714586076 then Roman and Greeks followed by ancient Egyptians and millions of Muslims all over the word ${ }^{(6)}$.

Active components in Miswak plant parts ${ }^{(1,7)}$ are varied in their chemical formula, structure, concentration, action, extraction method, an others. They may be organic or inorganic, charged or neutral, water- or fatsoluble.

Miswak has antioxidant, antifungal, antibacterial, anti-inflammatory affects and it possess anti-plaque properties $^{(8,9,10,11,12,13)}$.

Summary from chemical, biological, and pharmaceutical notes: Extract of miswak exerts important medicinal activities depending on its chemical contents. It contains benzyl isothiocyanate, alkaloids, tannins, glycosides, terpenes, flavonoids, fatty acids, silicon, potassium, sodium, calcium, magnesium, manganese, phosphorus, fluorine, sulfur, and others (Figure 1). These active components may be ranged in their concentration reflecting environmental impacts on any plant especially natural one $\mathrm{e}^{(1,14,15,16)}$.

Aqueous extract of its root, stem, or leaf has an effective inhibition impact on some bacteria ranged from low to moderate, but not high antimicrobial response $^{(17,18,19,20)}$ as a result of presence several organic and inorganic compounds ${ }^{(21,22,23)}$. 
Anyplant part having various active components which are responsible of different influence upon specific biological problem ${ }^{(22,23,24,25)}$. Miswak used to treat diuretic, gastritis, anacylost-omiasis, gonorrhea, inflamm-atory, hypolipidemic, anti-pyretic, ulcers caused by alcohol or psychological stress, and hypoglycemic. Lowering chol- esterol plasma or oral Candidiasis of patient with renal transplant situation can be achieved with miswak using. Also, it possesses other important agents to treat analgesic, malaria, alexiteric, astringent, leucoder- ma, scabies, venereal, and other diseases. Miswak applications are in general in dental hygiene but it showed a noticeable influence in viral resistance, wound healing, antiphlogistic, anastringent, and antimycotic activities, gingiva,-stimulation and depressant activity $(1.26,27,28,29,30,31,32,33,34,35,36,37)$.

Ahmad and Ahamed in their published article ${ }^{(28)}$ reviewed miswak chemical contents and its actions in biological systems. Also, in this review ${ }^{(28)}$ and other published papers researchers ${ }^{(25,27,30,32,34,36)}$ ensured that miswak phytochemical contents varied from organic to inorganic materials with remarkable properties (Figure 1.). For example, they contain many elements support like silicon in the form of silicate providing the necessary strength to perform its mechanical action. Many fatty acids, polysaccharides, phenol and furan derivatives in lignins, thio- compounds, and sterols are presented in plants parts varied in their concentrations like palmitic acid, myristic acid, lauric acid, salvadoside, salvadoraside, salvadorine, trimethyl amine, sitosterol, liriodendrin, syringing, rutin, quercetin, different amide forms, ascorbic acid, $\beta$-sitosterol, mustard oil, tannins, saponins, beside high fluoride and chloride contents (Figure 1.) $)^{(25,27,30,32,34,36)}$. According to a published study, miswak root contains oil that may be obtained by steam distillation consisting of benzyl isothiocyanate as the major component beside flavonoids, $\alpha$-pinene, and limonene ${ }^{(21)}$. Essential oil of this plant currently under review had a major content of benzyl thiocyanate and benzyl nitrile with less than $7 \%$ of benzaldehyde, carvacrol, aniline and naphthalene. Here, ascorbic acid (vitamin C) with thio - compound and all plant active components present a defense wall against bleeding, plaque, gingival bleeding and inflammatory actions ${ }^{(29)}$.

Various studies showed the capability of miswak extract to form new composites having metal oxide or polymer with qualified properties differed from the original material. The properties of the obtained composites may have a raise in chemical, physical, biological, or mechanical characters. Miswak extract is considered as an effective substance when mixed with other materials to produce homogenized nanocomposite, confirming that this step is an eco-friendly method with good results comparing with the absence of extract use $^{(38,39)}$.

Benzyl thioisocyanate abbrev- iated by BITC is the main component in miswak and other plants with various biological activities and according to http://pubchem. ncbi.nlm.nib.govwebsite, BITC is used as food flavor with warning that it causes eye and respiratory irritation as a pure chemical.

Bioactivity of miswak: Evaluation of the biological effects of chemicalsis depend upon several factors such as chemical structure, biological target, concentration, physical conditions, $\mathrm{pH}, \ldots$...tc.

For example, thiocyanate, nitrate, sulfate, or chloride ion that found in Miswak ${ }^{(40)}$ influenced oxygen, some aminoacidormonosaccharide transport, phosphorylation. Bacteria or virus can be inhibited by several mechanisms including enzyme action on sulfhydryl group and this group can be reacted with hypothiocyanite - Hydrogen peroxide catalyzed by lactoperoxidase ${ }^{(41,42,43)}$ as shown in Figure 2. Hypothiocyanite anion production may be increased or inhibited with the presence of plant extract like miswak extract to control acid production effect on tooth. These anions may be released during hydrolysis with variation in concentration in all plant parts ${ }^{(44)}$.

In biological systems, oxidation - reduction reaction may occur by the same starting materials with different products depending upon $\mathrm{pH}$ or enzyme. Glucosionlate group found in various plant families as a secondary products of metabolic pathways with three subgroups containing aliphatic $\alpha$ - amino acids, glucose, and sulfur atom $^{(44)}$.

Hydrolysis of this group is influenced by the $\mathrm{pH}$ factor producing nitrate, sulfate, and glucose at low $\mathrm{pH}$ while neutral condition give organic isothiocyanate compounds beside sulfate and glucose. Myrosinase enzyme catalyzes organic isothiocyanates to their alcohol and thiocyanate. These isothiocyantes act as signaling, anticarcinogenic, and detoxification molecules beside others biological actions ${ }^{(42,45,46,47,48,49)}$. 
$\theta$<smiles>[B]C1C(CC)OC(Oc2ccccc2)C(S([B])(=O)=O)C1O</smiles><smiles>[B]CC1OC(Oc2c(OC)cc(C3COC(c4cc(OC)c(OC5OC(C[B])C([B])C([B])C5S([B])(=O)=O)c(OC)c4)C3C[18O])cc2OC)C(S([B])(=O)=O)C([B])C1[B]</smiles><smiles></smiles>

Figure 1. Chemical structures of several active components in miswak.

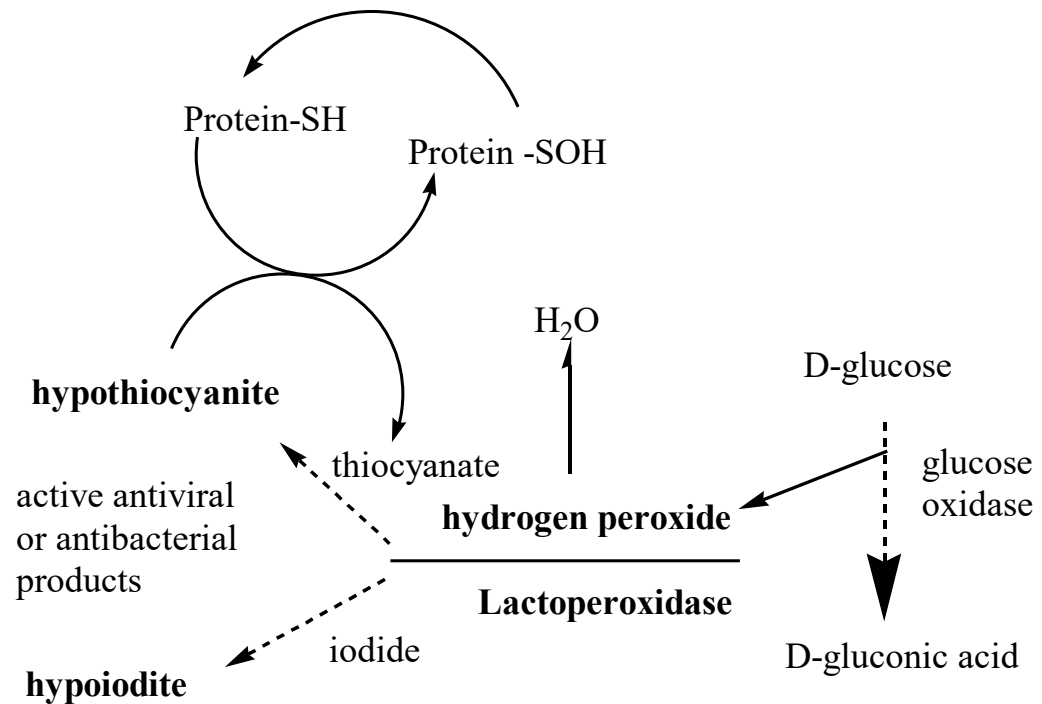

Figure 2. Antimicrobial products mechanism. 
Nitrogen organic and inorganic components may be presented in any plant parts that may converted to another different compounds causing various effects depending upon their chemical structures and other factors. Oxidation - Reduction of nitrogen compounds like ammonia, urea, nitrate, nitrite, amino acid, peptide, protein, ... etc. may result in ecosystem antimicrobial $\operatorname{activity}^{(50,51,52)}$.

Organic and inorganic nitrogen - sulfur compounds in plants varied in their structures and functions in plants itself or in other biological systems ${ }^{(53,54,55,56,57)}$.

Thiocyanate is one of these active acidic component found in various biological systems by being a part of human or enter human body through daily intake plants or animal products ${ }^{(58)}$. This important metabolism product utilizes several important actions even with its low concentration in human tear $(150 \mu \mathrm{M})$, human breast milk $(100 \mathrm{nM})$, while cow milk $(170 \mu \mathrm{M})$ through its bacteriostatic function. Accumulation of it leads to biological toxicity that can be lowered by renal elimination in human. Thiocyanate- hydrogen peroxide system catalyzed by peroxidase enzyme produces the antimicrobial agent (hypothiocyanous acid, HOSCN) that crosses cell wall of bacteria then reacting with sulfuhydryl (-SH), nitrogen, or selenium containing material to form (S-S), (S-O), (S-N), or (S-Se) bonds giving its antibacterial performance in many sites like oral cavity and saliva. This HOSCN may inhibit the growth of oral fungi or echovirus towards improving lung role ${ }^{(59,60,61,62,63,64)}$.

In general, thiocyanate is less toxic than cyanide $\left(\mathrm{CN}^{-}\right)$and it is eliminated by kidney. This toxicity did not prevent researchers from using thiocyanate as an oral under controlling dose to avoid sensitizing or suicide cases in Central Nervous, thyroid, skin, or renal system or any related toxicity of $\mathrm{SCN}^{-}$as a metabolite of cyanogenic drug, dietary, or smoking ${ }^{(65,66,67)}$.

Chlorine atom in its ionic form is another important micronutrient found in plant parts with biological importance even at low needed concentration ${ }^{(68)}$. It controls many activities in plant and other biological systems like electric charge balance, cell osmotic, enzyme, ionic, $\mathrm{pH}$, and water regulations that contribute in other biological performances such as growth, ion - ion interchangeable operation, or disease resistance. Published articles confirmed that chloride ion can be replaced by other important anions (phosphate, sulfate, or nitrate). This replacement is with important influence because chloride accumulation causes salt stress and toxicity, especially in plants and microbiological systems $^{(69,70,71)}$.

The essential micronutrient $\left(\mathrm{Cl}^{-}\right)$can be found in almost biological systems as a consequence of high solubility of its salts in water towards various maintaining functions ${ }^{(51,72)}$ such as catalytic protein or enzyme activator in plant or animal, controlling carbon dioxide concentration in cell, oxygen role in photosystem II or redox processes, energy production and consuming, fungicide treatment, and anion : cation balance.

Bio- data showed that chloride ion have a noticeable cell membrane crossing of different bio-systems and this transportation can be done in cooperation with necessary cations and/or anions. This collaboration produces nitrogen fixation, photosynthesis of organic or inorganic nitrogen compounds towards effective regulation or accumulation between acidic and basic compounds or ions depending on required and/or produced energy for each process. These cooperative processes raise some important bio-functions like plant growth and production of active components or macromolecules for example in plant tissues ${ }^{(70,71,73) \text {. }}$

In conclusion, all the mentioned activities of active components may be performed in the target bio-system or its production. So, these organic/inorganic active ingredients varied in their concentrations, extraction method, contributions with other ingredients, and applications. Their roles under question mainly based on structure, medium, and target. For example, chloride plays major role in cell expansion accompanied by other ions and organic molecules. Also, biological activity of any ingredient can be performed through enzyme catalysis that needs specific anion assistance. So, miswak have different active organic and inorganic compounds work together to achieve the biological actions.

Partitioning of the important chemical components in miswak ${ }^{(74)}$ : Mohamed et al. (2018) was able to separate the active chemical compounds of miswak by cutting $1.1 \mathrm{~kg}$ of miswak roots to small pieces and treated them with alcoholic solvent $(75 \%$ ethanol) by cold socking. After filtration step, the filtrate was concentrated under reduced pressure to obtain brown residue. To the dried extracts, $200 \mathrm{~mL}$ distil water and $400 \mathrm{~mL}$ petroleum ether was added. The upper layer (petroleum ether) was introduced into silica gel column 
and n-Hexane-Ethyl acetate was used to elute the two compounds. Fractionation of compounds was carried out using $5 \%$ and $7 \%$ acetonitrile in water $\left(\mathrm{H}_{2} \mathrm{O}: \mathrm{CH}_{3} \mathrm{CN}\right)$. Compound (3) was eluted by $5 \%$ and compound (4) eluted by $7 \%$. The aqueous layer was treated with 150 $\mathrm{mL} 0.2 \mathrm{~N} \mathrm{HCl}$ and $300 \mathrm{ml}$ chloroform and shaken for 16 hrs. The chloroform layer was subjected to silica gel column and $\mathrm{CHCl}_{3}-\mathrm{MeOH}$ was used as elution agent. $1 \% \mathrm{MeOH}$ was used to elute compound (2) and $15 \%$ $\mathrm{MeOH}$ is suitable to elute compound (1).

Ammonium hydroxide was added to the aqueous layer until $\mathrm{pH}$ reach 11, then $400 \mathrm{~mL}$ of chloroform was added and mixed well.

Alkaloid Rich Fraction can be obtained by chloroform evaporation. After this fraction was subjected to column of silica gel, $78 \% \mathrm{MeOH}$ in $\mathrm{H}_{2} \mathrm{O}$ can elute compound (5), while compound (6) can be obtained by direct crystallization

From $1.1 \mathrm{~kg}$ of miswak roots, the above partition process can produce the following amounts:

$8 \mathrm{mg}$ sulphur-containing imidazoline alkaloid (persicaline) compound (4).

$13 \mathrm{mg}$ Benzyl-thiocarbamicacid-O-ethyl ester compound (3).

$30 \mathrm{mg}$ hexadecanoic acid benzylamide
compound(1).

$18 \mathrm{mg}$ benzyl isothiocyanate compound(2).

21 mg N-benzyl-2-phenylacet- amide compound(5)

7 mg Benzylurea compound(6)

Literature review of the method of obtaining miswak extract: The collected roots were washed, dried, and grinded to small size, followed by treating with $50 \%(\mathrm{v} / \mathrm{v})$ ethanol in distill water by mixing the ratio of $1: 10$ root/solvent in dark space at $25 \mathrm{C}^{\circ}$ for 24 $\mathrm{hr}$, then filter paper (Whatman No. 1442) used to filter the solution twice. The liquid concentrated by vacuum rotary evaporator at high temp, to get a dark brownish miswak extract( ${ }^{(75)}$.

Collected miswak were dried at the shade and then powdered by grinder to fine particles. Using soxhlet extractor, the powder was treated with different solvents such as methanol, ethanol and the mixture of both solvents. After drying step, the extracts were weighed in DMSO for antibacterial activity purpose ${ }^{(76)}$.

Miswak were cutted into small pieces after washing step by distil water and kept 14 days at room temp. to be full dry. $100 \mathrm{~g}$ of dried miswak powder were mixed with either $1 \mathrm{~L}$ of $95 \%$ methanol (as alcoholic solvent) or $1 \mathrm{~L}$ distil water (as aqueous solvent). Filtration step were carried out using Whatman filter paper no, 1 and then the filtrates were concentrated using vacuum evaporator at $60{ }^{\circ} \mathrm{C}$ (for both water and alcoholic solvent). The extracts stored under $-20^{\circ} \mathrm{C}$ for the later use ${ }^{(77)}$.

By tap water, roots of miswak were washed and then (300-400) $\mathrm{g}$ in $1500 \mathrm{~mL} 80 \%$ ethanol were dissolved for $0.5 \mathrm{hr}$. at $80^{\circ} \mathrm{C}$. The filtration step was carried out using cotton wool. To be sure for complete extraction, the residue was dissolved again in $1 \mathrm{~L}$ of the same solvent for $5 \mathrm{~min}$. using water bath at boiling point degree and kept overnight to be filtered again by a cotton wool. Both filterates (step 1 and 2) were mixed and concentrated by rotary evaporator at $40{ }^{\circ} \mathrm{C}$. The produced extracts were stored at $-80^{\circ} \mathrm{C}^{(78)}$.

After drying the miswak plants for 10 days at room temperature, they were cutted by Omni mixer to small parts. 20 grams of the dried powder were mixed with $100 \mathrm{~mL}$ of deionized water and kept to soak at $4^{\circ} \mathrm{C}$ for 24 hrs. and then centrifuged at low temperature $\left(4^{\circ} \mathrm{C}\right)$ and then filter the supernatants by very small pore membrane $(0.45 \mu \mathrm{m})$ membrane. finally, freezedried was carried out to get dry miswak.

Saleh et al. used different types of solvents such as acetone, ethanol, methanol (all were 80 percent in water) in addition to distilled water where percent of miswak to solvent was $(1: 10, \mathrm{wt} / \mathrm{v})$. After filtration step, the extracts were concentrated by vacuum evaporator ${ }^{(79)}$.

Chevalier (2003) use modified procedure to obtain miswak extracts. After cutting the sticks of miswak to small pieces, food blender was used to ground the pieces to powder. Sterile hot distilled water was added to miswak powder with 1:10, wt/v (miswak:water) and left to sock at $37^{\circ} \mathrm{C}$ for $48 \mathrm{hrs}$. then the mixture was filtered by $0.45 \mu \mathrm{m}$ pore filter paper. Drying of the extracts was established by incubation system at $37^{\circ} \mathrm{C}$. The final extracts were stored at sterilized vials in refrigerator system $^{(80)}$.

Firas et al. used soxhlet extractor to recover Salvadora persica $L$. by methanol solvent for $10 \mathrm{hrs}$. 
The experiment still continued until the solvent became colorless. Rotary vacuum evaporator was used at $40{ }^{\circ} \mathrm{C}$ to concentrate the extracts and kept store until use ${ }^{(81)}$.

Darmani et al. mixed 1.5:10 w/v of miswak powder: sterile water for $48 \mathrm{hrs}$. at $4^{\circ} \mathrm{C}$ after drying the fresh sticks at room temperature for 2 days, (miswak powder was obtained using ball mill). The treated material was centrifuged and filtered by $0.45 \mu \mathrm{m}$ pore filter paper $^{(82)}$.

Miswak as potent dental materials: The Salvadora persica (the scientific name for Miswa)" has great beneficial effects on the oral cavity, like the silica and sodium bicarbonate which are constituents of miswaq,work as abrasive materials, reduce the tooth stains and improve its whiteness ${ }^{(83)}$.

Plaque and gingivitis usually reduce in Miswak users due to the "Tannic Acid" which is an astringing material $^{(84,85)}$.

Other constituents can protect the tooth enamel by a layer of resin, while alkaloid has a bacteriocidal effect $^{(86,87)}$, supported by sulfur present in Salvadora persica $^{(88)}$.

Calculus formation usually inhibited by high concentration of chlorine ${ }^{(87)}$.

Inhibition of demineralization and promotion of remineralization is achieved due to the calcium saturation of saliva of Miswak users ${ }^{(89)}$.

Benzylisothiocyanate (BITC), one of the S. Persica root showed a virucidal activity specially against herpes simplex, also it can inhibit the growth of Streptococcus mutans, as many reports support its fungistatic action against Candida albicans ${ }^{(90,91,92)}$.

Depending on significant effects of Miswak extracts against the oral cavity pathogens, it is recommended to use Miswak as a dental hygiene method to prevent tooth caries.

High concentrations of Miswak extract works as good as chemical oral disinfectant (e.g. Triclosan and chlorhexidine) showing antibacterial actions $^{(4,89,90,91,92,93,94)}$. Also Alcoholic and aqueous extract of $S$. persica showed anticandidal activity ${ }^{(93,95)}$.

Different investigations showed significant inhibition of the growth of different oral pathogens like Candida albicans and actinomyces naeslundii ${ }^{(91)}$.
Himawan H. etal. observed that Miswakis more potent than ordinary toothpaste in its ability to reduce the amount of plaque accumulation in fixed orthodontic. Two groups (20 patients for each group) were examined, $95 \%$ reduction in the plaque score was recorded when Miswak is used, against $65 \%$ reduction in the ordinary toothpaste ${ }^{(96)}$.

Almas K. studied the effect of miswak and Chlorahexidine Gluconate (CHX) on the removal efficiency of smear layer. He recorded that miswak was more potent than $\mathrm{CHX}$ to remove the layer. He also observed that dentinal tubules were more opened in both etched (periodontal and healthy dentin) ${ }^{(97)}$.

Organic acids are produced due to the fermentation of sucrose which is metabolized by biofilm bacteria resulting in decrease the plaque $\mathrm{pH}$ which causes dental caries according to Stephan curve. Lower $\mathrm{pH}$ can demineralize the enamel and cause caries. Because of strong taste of miswak, rinsing with its extract increases salivary flow and secretion from parotid gland which leads to raise the $\mathrm{pH}$ plaque after half hr. and prevents dental caries ${ }^{(98)}$.

Mixture ofmiswak (3.5\%) and monofluorophosphate $(0.8 \%)$ enhance significantly the plaque reduction and improve the gingival index ${ }^{(99,100)}$.

\section{Conclusion}

Miswak (as chewing sticks) is one of the most popular important herbs used for good dental health due to its active chemical components which are considered the main keys of the potent bioactive properties that relate to its therapeutic characteristics. Miswak is considered (by World Health Organization/WHO) as a safe tool for healthy tooth. Anti-plaque properties of miswak is very significant to prevent dental caries. Antioxidant, antiphlog- istic, anticarcinogenic, antifungal, antimicrobial, antibacterial, antimycotic, and anticandidal behaviors of miswak represent the real reasons of its therapeutic characteristics for oral tooth health.

\section{Conflict of Interest: Nil}

Sources of Funding: Self-funding.

Ethical Clearance: Not required 


\section{References}

1. Ahmad H, Rajagopal. Salvadora persica L. (Meswak) in dental hygiene. Saudi J Dent Res. 2014; 5(2), 130-134.

2. Mohammad M, and Saeed A. A review of the therapeutic effects of using miswak (Salvadora Persica) on oral health,Saudi Med J. 2015;36(5): 530-543.

3. Hyson J. History of the toothbrush. J Hist Dent. 2003;51:73-80.

4. AlOtaibi M, Batwa S, Bergstrom J, and Batwa $M$. The effectiveness of chewing stick miswak on plaque removal. Saudi Dent J. 2006;18(3):125-133.

5. Darout I, Christy A, Skaug N, Egeberg P. Identification and quantification of some potentially antimicrobial anionic components in miswak extract. Indian J.Pharmacol. 2000; 32, 11-14.

6. Chawla H.S. A new natural source for topical fluoride. J Indian Dent Assoc. 1983; 55:419-422.

7. Albabtain R, Azeem M, Wondimu Z, Lindberg $\mathrm{T}$, Karin A, and Gustafsson A. Investigations of a Possible Chemical Effect of Salvadora persica Chewing Sticks. Evid. Based Complementary Altern. Med. 2017; 2017:2576548. doi: 10.1155/2017/2576548.

8. Bayan A, Ismail A, Chandraprabha M, Ahmed Al., Amr A.Salvadora persica (Miswak): Antioxidant and Promising Antiangiogenic Insights, Am J Plant Sci, 2018;9(6):1228-1244.

9. Abhishek G., Shikhar V., Pradeep K., Sharad S., Rawat A., Phytochemical and Antioxidant Studies of Salvadora persica L. Stem \& Twig. Indian J Pharm Educ. 2015;49(1):71-75.

10. Fayez N, Mustafa N, Zohaib K, Muhammad S, and Khalid A. Role of Salvadora persica chewing stick (miswak): A natural toothbrush for holistic oral health.Eur J Dent. 2016;10(2):301-308.

11. Jamal A, Khalid A,Siddique, A. A review on phytochemical and miswak (Salvadora persica Linn). J Pharm Bioallied Sci. 2011;3(1): 113-117.

12. Saddiq A, Monagi H.Fungicidal Impact of Salvadora persica L. (Miswak) Extract on Growth of Foodborne Pathogens, Aspergillus Species. Dose response. 2019:17(3):15593258- 1987621.

13. Noumi E, Snoussi M, Hajlaoui H, Valentin E, Bakhrouf A., Antifungal properties of Salvadora persica and Juglans regia L. extracts against oral
Candida strains. Eur J Clin. Microbiol Infect Dis. 2010; 29(1): 81-8.

14. Bahabri F. Application of spectroscopic techniques for the identification of organic and inorganic constituents of Salvadora persica from Saudi Arabia. Physica A. 2000; 276, 346-351.

15. Halawany H. A review on miswak (Salvadora persica) and its effect on various aspects of oral health. Saudi Dent J. 2012; 24(2):63-69.

16. AbdelKader M, Alam P, AlQarni M, Salkini M. High - Performance Thin-Layer Chromatographic method for the estimation of benzyl thioisocyanate in Salvadora persica root extract and dental care herbal products. J. Planar Chromatogr. 2017;30(3):211-215.

17. Al-Lafi T, Ababneh H. The effect of the extract of the miswak (chewing sticks) used in Jordan and the Middle East on oral bacteria. Int. Dent. J. 1995; 45:218-222.

18. AlMas K, AlBagieh N. The antimicrobial effect of bark and pulp extracts of miswak, Salvadora persica. Biomed. Lett. 1999; 60:71-75.

19. Abd El Rahman H, Skaug N. George W. In vitro antimicrobial effects of crude miswak extracts on oral pathogens. Saudi Dent J. 2002;14:26-32.

20. Sofrata A, Claesson R, Lingström P, Gustafsson A. Strong antibacterial effect of miswak against oral microorganisms associated with periodontitis and caries. J Periodontol. 2008;79:1474-1479.

21. AlAli F, AlLafi T. GC-MS analysis and bioactivity testing of the volatile oil from the leaves of the toothbrush tree of Salvadora persica L. Nat Prod Res. 2003; 17:189-194.

22. Abdel Kader M, Alam P, AlQarni M, Salkini M. High-Performance Thin-Layer Chrom- atographic method for the estimation of benzyl thioisocyanate in Salvadora persica root extract and dental care herbal products. J. Planar Chromatogr. 2017;30(3):211-215.

23. Farooqi M, Srivastava J. The tooth-brush tree (Salvadora persica). Quart. J. Crude Drug Res. 1968; 8, 1297-1299.

24. Garbouri S, Karlson A, Palsson K. Tick repellent properties of three Libyan plants. J Med Entomol. 2009; 46(6), 1415-1419

25. Kamil M, Jayaraj A, Ahmed F, Gunaseklar C, Samuel S, Habibul M, Chan K. Pham- acognostic 
and phytochemical studies on Salvadora persica. J Pharm Pharmacol. 1999; 227, 51-58.

26. Mansour M, Al Khateeb T, Al Mazraoo A. The analgesic effect of miswak. Saudi Dent J. 1996; 8, 87-91.

27. Alili N, Türp J, Kulik E, Waltimo T. Volatile compounds of Salvadora persica inhibit the growth of oral Candida species. Arch. Oral Biol. 2014; 59(5), 441-447.

28. Ahmad H, Ahamed N. Therapeutic properties of miswak chewing sticks: A review. African J Biotechnol. 2012;11(83):14850-14857.

29. Noumi E, Snoussi M, Trabelsi N, Hajlaoui H, Ksouri R, Valentin E, Bakhrouf A. Antibacterial, anticandidal, antio-xidant activities of Salvadora persica and Juglans regia L. extracts. JMed Plants Res. 2011;5(17):4138-4146.

30. Sher $H, A l$ Yemeni $M$, Yaha $S$, Arif $H$. Ethnomedicinal and ecological evaluation of Salvadora persica L.: a threatened medicinal plant in Arabian Peninsula. J Med Res. 2010;4(12):12091215.

31. Khalessi A, Pack W, and Tompkins G. An in vivo study of the plaque control efficacy of Persica ${ }^{\mathrm{TM}}$ : a commercially avail- able herbal mouthwash containing extracts of Salvadora persica. Int Dent J. 2004;54: 279-283.

32. Ahmed S, ElGengaihi E, ElSayed M, Schung E. Preliminary phytochemical and propagation trial with Salvadora persica L. Agric For Res. 2008; 58(1-2):135-138.

33. Amoian B, Moghadamnia A, Barzi S, Sheykholeslami S, Rangiani A. Salvadora persica extract chewing gum and gingival health: Improvement of gingival and probe-bleeding index. Compl Therp Clin Prac. 2010;16(3):121-123.

34. Eid M, Selim H, AlShammery A. The relationship between chewing sticks (miswak) and periodontal health . Part I. Review of the literature and profile of the subjects. Quintessence Int. 1990; 21(11), 913-917

35. Trovato A, Galati E, Rossitto A, Moriforte M, D'Aquino A, Forestieri A. Hypoglycemic effects of Salvadora persica L. in the rat. Phytomed. 1998;5(2), 129-132.

36. Khalil A. Benzyl amides from Salvadora persica. Arch. Pharm. Res. 2006;29(11), 952-956.
37. Sanogo R, Monforte M, Daquino A, Rossitto A, Maur D, and Galati E. Antiulcer activity of Salvadora persica L.: struc- tural modifications. Phytomed. Int. J. Phytotherp. Phyto- pharmacol. 1999;6(5),363 - 366.

38. (a) ElTatari A., de Soet J., de Gee A., Abou Shelib M., and Amerongen W. Influence of Salvadora persica (miswak) extract on physical and antimicrobial properties of glass ionomer cement. Eur Archives Paediatr Dent. 12, 22-25 (2011); (b) Savaş S. Structural properties and mechanical performance of Salvadora persica L. (Miswak) reinforced polypropylene composites. Polym Compos. 40, E663-E677 (2018).

39. Ahmadi R, Ghanbarzadeh B., Ayaseh A, Kafil H, Özyurt H, Katourani H, and Ostadrahimi A. The antimicrobial bio-nanocomposite containing nonhydrolyzed cellulose nanofiber (CNF) and miswak (Salvadora persica L.) extract. Carbohydr Polym. 2019;214:15-25.

40. Yarbrough J, Rake J, Eaagon R. Bacterial inhibitory of nitrate inhibition of active transport, but not of group translocation and of intercellular enzymes. Appl En- viron Microbiol. 1980;39, 831-834.

41. Carlsson J, Edlun M, Häström L. Bactericidal and cytotoxic effects of hypo- thiocyanate - hydrogen peroxide mixtures. Infect. Immun. 1984;44(3),581586.

42. (a) AlShehri S, Duley J, Bansal N. Xanthine oxidase-lactoperoxidase system and innate immunity: biochemical actions and physiological roles. Redox Biol. 2020;34, 101524; (b) Cegolon L. Investigation hypo- thiocyanite against SARSCoV-2. Int J Hyg Environ Health. 2020; 227, 113520.

43. Kalanaraman B. Teaching the basics of redox biology to medical and graduate students: oxidants, antioxidants and disease mechanisms. Redox Biol. 2013; 1(1), 244-257

44. Ishida M, Hara M, Fukino N, Kakizaki T, Morimitsu Y. Glucosinolate metabolism, functionality, and breeding for the improvement of Brassicaceae vegetables. Breed Sci. 2014; 64(1), 48-59.

45. Rouzaud G, Young S, Duncan A. Hydrolysis of glucosinolate to isothiocyanates after ingestion of raw or microwaved cabbage by human volunteers. Cancer Epideminol Biomarker Prev. 2004;13(1), 125-131. 
46. Johnson I. Glucosinolates: bioavailability and importance to health. Int J Vit. Nutr Res. 2002; 72, 26-31.

47. Luke L, Wagstaff C. Enhancement of glucosinolate and isothiocyanate profiles in Brassicaceae crops: addressing challenges in breeding for cultivation, storage, and consumer-related traits. J Agric Food Chem. 2017; 65, 9379-9403.

48. Lugasi A, Varga T. non-nutritive biologically active plant components: glucosinolates, their sources and their nutritional significance. Orv Hetil 2006; 147(29), 1361-1368.

49. Bo S, Fadda M, Fedele D, Pellegrini M, Ghigo E, Pellegrini N. A critical review on the role of food and nutrition in the energy balance. Nutr. 2020; 12(4), 1161.

50. Kraiser T, Gras D, Gutiérrez A, González B, Gutiérrez R. A holistic view of nitrogen acquisition in plants. J. Exp. Bot. 2011; 62(4), 1455-1466.

51. Aibara I, Miwa K. Strategies for optimization of mineral nutrient transport in plants: multilevel regulation of nutrient -dependent dynamic of root architecture and transporter activity. Plant Cell Physiol. 2014; 55(12), 2027-2037.

52. Kiba T, Krapp A. Plant nitrogen acquisition under low availability: regulation of uptake and root architecture. Plant Cell Physiol. 2016; 57(4), 707714.

53. Aune T, Thomas E. Accumulation of hypothiocyanite ion during peroxidase -catalyzed oxidation of thiocyanate ion. Eur J Biochem. 1977; 80, 209-214.

54. Cooper R, Williams J. Elemental sulphur as an induced antifungal substance in plant defence. $\mathrm{J}$ Exp Bot. 2004;55, 1947-1953.

55. Cooper R, Williams J. Elemental sulphur is produced by diverse plant families as a component of defense against fungal and bacterial pathogens. Physiol. Mol. Plant Pathol. 2003; 63, 3-16.

56. Tea I, Gentr T, Naulet N, Boyer V, Lummerzheim $\mathrm{M}$, and Kleiber D. Effect of foliar sulfur and nitrogen fertilization on wheat storage protein comp- osition and dough mixing properties. Cereal Chem. 2004; 81,759-766.

57. Tolocka M, Turpin B. Contribution of organosulfur compounds to organic aerosol mass. Environ Sci Technol. 2012; 46, 7978-7983.
58. Xulu B, Ashby M. Small molecular, macromolecular, and cellular chloramines react with thiocyanate to give human defense factor hypothiocyanite Biochem. 2010;49, 2068-2074.

59. Schultz C, Ahmed M, Dawes C, Mantsch H. Thiocyanate level in human saliva: quantitation by Fourier Transform Infrared Spectroscopy. Anal Biochem. 1996; 240, 7-12.

60. Ashby $M$, Inorganic chemistry of defensive peroxidases in human oral activity. J Dent Res. 2008;87, 900-914.

61. Thomas E, Milligan T, Joyner R, Jefferson M. Antibacterial activity of hydrogen peroxide in the lactoperoxidase-hydrogen peroxide -thiocyanate system against oral streptococci. Infect Immun. 1994; 62, 529-535.

62. Klebanoff S, Clem W, Luebke R. The peroxidasethiocyanate-hydrogen peroxidase antimicrobial system. Biochim Biophys Acta 1966; 17, 63 - 72.

63. Hawkins C. The role of hypothiocyanous acid (HOSCN) in biological systems. Free Radic. Res. 2009; 43, 1147-1158.

64. Chandler J, Day B. Thiocyanate: a potentially useful therapeutic agent with host and antioxidant properties. Biochem Pharmacol. 2012;84(11),13811387.

65. Bhunia F, Saha N, Kaviraj A. Toxicity of thiocyanate to fish, plankton, worm, and aquatic ecosystem. Bull Environ Contamin Tox. 2000;64,197-204.

66. Trugo L, Finglas P. The Encyclopedia of food and nutrition, $8^{\text {th }}$ Edition, Elsevier Science Ltd, New York, USA, 2003.

67. Smith R. Cyanate and thiocyanate: acute toxicity. Proceed Soc Exp Biol Med. 1973; 142(3), 10411044.

68. Hänsch R, Mendel R. Physiological functions of mineral micronutrients ( $\mathrm{Cu}, \mathrm{Zn}, \mathrm{Mn}, \mathrm{Fe}, \mathrm{Ni}, \mathrm{Mo}, \mathrm{B}$, Cl). Curr. Opinion Plant Biol. 2009; 12, 259-266.

69. White P, Broaley M. Chloride in soil and its uptake and movement within the plant: a review. Annals Bot. 2001;88, 967 -988.

70. Broadley M, Brown P, Cakmak I, Ma J, Rengel Z, F. Zhao F, Marschner P. Function of nutrients: micronutrient. Marschner's mineral nutrition of higher plants, $3^{\text {rd }}$ edition, Academic Press, San Diego, USA, 2012.

71. Franco-Navaro J, Brumós J, Rosales M, Cubero- 
Font P, Talón M, Colmenero-Flores J. Chloride regulates leaf size and water relations in tobacco plants. J Exp Bot. 2016; 67(3), 873-891.

72. Raven J. Chloride: essential micronutrient and multifunctional beneficial ion. J Exp Bot. 2017; 68(3), 359-367.

73. Xu G, Magen H, Tarchitky J, Kafkafi U. Advances in chloride nutrition of plants. Adv. Agron. 1999; $68,97-150$.

74. MohamedF, Wael M, Omer B, Ali El, Persicaline, A New Antioxidant Sulphur-Containing Imidazoline Alkaloid from Salvadora persica Roots, Molecules. 2018, 23, 483:1-13

75. Alhamdi R, Tanomand A, F. Kamounah F, Ayaseh A, Ganbarov K, Yousefi M. Katourani A, Yousefi B, and Kafil H. Fabrication and characterization of a titanium oxide $\left(\mathrm{TiO}_{2}\right)$ nanoparticles reinforced bio-nanocomposite containing miswak (Salvadora persica) extract - the antimi- crobial, thermophysical, and barrier properties. Int J Nanomed. 2019;14:3439-3454.

76. Abd ElLatif H, Sulaiman A. A., Antibacterial activity of Miswak (Salvadora persica) extracts against isolated and genetically identified oral cavity pathogens, Technol. Health Care. 2016:24:S841S848

77. Mohamed S., Ahmed M., Mohamed A., Hany G., and Abduljabbar H., Antibacterial Activity of Salvadora persica L. (Miswak) Extracts against Multidrug Resistant Bacterial Clinical Isolates, Evid. Based Complementary Altern. Med. 2016:15.

78. Mohamed M, Abdul Aziz A, Ibrahim A, Ali A, Mostafa E, EL-Gaaly G, Assessment of antioxidant activities in roots of Miswak (Salvadora persica) plants grown at two different locations in Saudi Arabia Saudi. Res J Biol Sci. 2015: 22, 168-175.

79. Saleh A,Jalaluddin A. Antioxidant capacity of chewing stick miswak Salvadora persica. BMC Complement Altern Med. 2013,13:40.

80. Kadhum S, Sabah N, Mauyad S. Antifungal efficiency of Miswak \& Cardamom Extract on Some Virulence Factors of Candida albicans as Oral Pathogen.Biolo J Kufa univ. 2011; 3(2): 1-7.

81. Firas A, Khudir D. In Vitro Antimicrobial Activity of Salvadora persica L. Extracts Against Some Isolated Oral Pathogens in Iraq. Turk $\mathrm{J}$ Biol. 2008;32:57-62
82. Darmani H, Nusayr T, Al-Hiyasat A. Effects of extracts of miswak and derum on proliferation of Balb/C 3 T3 fibroblasts and viability of cariogenic bacteria. Int J Dent Hygiene. 2006;4, 62-66

83. El Mostehy M.R, Al-Jassem AA, Al-Yassin IA. Miswak as an oral health device. Preliminary chemical and clinical evaluation. Hamdard. 1983;26:41-50.

84. H.S. A new natural source for topical fluoride. J Indian Dent Assoc. 1983; 55:419-422.

85. Kubota K, Tanaka T, Murata Y, Hirasawa M. Effect of tannic acid on adherence of Candida to denture base. J Den Res. 1988; 67:183.

86. Dorland WA. Newman. Dorland's Illustrated Medical Dictionary. 27th ed. Philadelphia: W.B.Saunders Co. 1988.

87. Almas K. Miswak (chewing stick) and its role in oral health. Postgrad Dent. 1993; 3:214-18

88. Grant J. Miswak-toothbrushes that grow on trees. Todays-FDA. 1990; 2:60.

89. Jaishree T, JareenAJ. The Miracle Twig-Miswak. Int JAppl Dent Sci. 2017; 3(2): 66-70.

90. Al-Bagieh NH. Antiherpes simplex virus type 1 activity of benzylisothiocyanate. Biomed.Lett. 1992; 47:67-70

91. Al-Bagieh NH. Effect of benzylisothiocyanate on the growth and acid production of Candida albicans. Biomed Lett. 1998;58:139-145.

92. Al-BagiehNH,WeinbergED.Benzylisothiocyanate: a possible agent for controlling dental caries. Microb Lett. 1998; 39:143-151.

93. Al-Bagieh NH, Idowu A, Salako NO. Effect of aqueous extract of miswak on the in vitro growth of Candida albicans. Microbios Lett. 1994; (80) 107113.

94. Ali H, Konig CM, Khalid SA. Evaluation of selected Sudanese medicinal plants for their in vitro activity against hemoflagellates selected bacteria, HIV-1-RT and tyrosine kinase inhibitory, and for cytotoxicity. J. Ethnopharmacol. 2002;83:219-228.

95. Deborah K, Mecky I., Olipa D, Cosam C, and Zakaria H. Screening of Tanzanian medi- cinal plants for anti-Candida activity, BMC Complement Dent pract. 2006;6:11, 1-10

96. Himawan H, Talitha A. The effectiviveness of using siwak toothpaste on plaque acuumalation in fixed orthodontic applications users. Asian J Pharm 
Clin Res. 2020;13(3):113-115.

97. Khalid A. The Effect of Salvadora Persica Extract (Miswak) and Chlorahexidine Gluconate on Human Dentin: A SEM Study. J. Contemp. Dent. Pract. . 2002;3(3);1-10.

98. Sote E. The relative effectiveness of chewing sticks and toothbrush on plaque rem- oval. Afr Dent J.1987;1:48-53.
99. Stafa M., Sadek S. The efficacy of Miswak concentrate, tooth paste: I. Clinical report, Egypt Dent J. 1987;33;75-84

100. Walter H, Lewis, Memory P.F. Elvin-Lewis, Medical Botany: Plants Affecting Human Health, $2^{\text {nd }}$ ed., Willey, page 412, 2003. 